\title{
Carbohydrate and Lipid Metabolism Following Infliximab Therapy in Pediatric Crohn's Disease
}

\author{
STEVEN J. STEINER, MARIAN D. PFEFFERKORN, JOSEPH F. FITZGERALD, AND SCOTT C. DENNE
}

Division of Pediatric Gastroenterology, Hepatology, Nutrition [S.J.S., M.D.P., J.F.F.], Division of Pediatric Neonatal-Perinatal Medicine [S.C.D.], Indiana University School of Medicine, Indianapolis, Indiana 46202

\begin{abstract}
Improvements in insulin resistance after anti-TNF- $\alpha$ therapy have been reported in inflammatory conditions, although no changes were noted in adult patients with Crohn's disease. There is no information concerning insulin resistance and substrate metabolism in children with Crohn's disease after anti-TNF- $\alpha$ therapy. Our aim was to describe changes in carbohydrate and lipid metabolism in children with active Crohn's disease after their initial dose of infliximab. Children with active Crohn's disease underwent measurement of plasma insulin and glucose just before and $2 \mathrm{wk}$ after their initial infusion of infliximab, an anti-TNF- $\alpha$ antibody. In addition, resting energy expenditure, with determination of both carbohydrate and lipid oxidation rates, was determined. Measurements were conducted in both fasting and parenterally fed states. Despite no changes in resting energy expenditure, a significant reduction $(p<0.05)$ in RQ (5\%) and carbohydrate oxidation rate $(24 \%)$, with a corresponding increase in lipid oxidation rate $(42 \%)$ was found during parenteral nutrition infusion. No differences in plasma insulin, glucose, and insulin resistance were noted when comparing pre- and postinfliximab measurements. (Pediatr Res 64: 673-676, 2008)
\end{abstract}

$\mathrm{T}^{\mathrm{s}}$ he use of anti-TNF- $\alpha$ agents for the treatment of a variety of diseases, including rheumatoid arthritis and Crohn's disease, has exploded over the last decade. The effect of anti-TNF- $\alpha$ agents on substrate metabolism, including carbohydrate and lipid metabolism, is of significant importance in pediatric patients, who frequently suffer from growth disturbances because of inflammatory disorders. Although TNF- $\alpha$ may affect glucose metabolism by increasing noninsulin dependent glucose transport and decreasing insulin dependent glucose transport, conflicting evidence of the action of infliximab on insulin resistance in otherwise healthy obese or insulin resistant subjects emerged from initial studies (1), including the observation that changes in insulin resistance were more readily observed in more obese patients (2).

The study of the effects of anti-TNF- $\alpha$ agents on insulin resistance in inflammatory conditions has produced conflicting evidence. In adult patients with rheumatoid arthritis, significant changes in glucose metabolism were noted after infliximab therapy. Gonzalez-Gay et al. (3) demonstrated an

Received March 3, 2008; accepted July 7, 2008.

Correspondence: Steven J. Steiner, M.D., Division of Pediatric Gastroenterology/ Hepatology/Nutrition, James Whitcomb Riley Hospital for Children, Indiana University School of Medicine, 702 Barnhill Drive/ROC 4210, Indianapolis, IN 46202-5225; e-mail: ssteiner@iupui.edu

This study was supported by a CReFF awarded to SJS by the GCRC at Indiana University School of Medicine, M01 RR000750, and from National Institutes of Health Grant RO-1 HD29153 (SCD). improvement in insulin resistance and sensitivity immediately after the infusion of infliximab, and Tam et al. (4) demonstrated decreased plasma insulin and decreased insulin resistance at $14 \mathrm{wk}$, following infliximab $(3 \mathrm{mg} / \mathrm{kg})$ at $\mathrm{wk} 0,2$, and 6. Among adult patients with rheumatoid arthritis and ankylosing spondylitis, Kiortsis et al. (5) found improvements in insulin sensitivity and resistance in those patients with the highest baseline insulin resistance. Huvers et al. (6) used the hyperinsulinemic-euglycemic clamp technique in eight patients with rheumatic disease, demonstrating improved insulin sensitivity $6 \mathrm{wk}$ after initiating infliximab therapy. Only limited data are available concerning changes in insulin sensitivity after infliximab therapy for Crohn's disease. In 10 adult patients with Crohn's disease, three to five infusions of infliximab resulted in no changes in fasting insulin and insulin resistance (7).

The effects of acute inflammation and nutritional depletion on substrate metabolism, and its reaction to nutritional rehabilitation and medical therapy, may provide information about how substrate metabolism in children with Crohn's disease will react to anti-TNF- $\alpha$ therapy. Septic patients are more dependent on lipid oxidation for energy, and in fact, continue to oxidize lipid even when the patient is provided excess carbohydrate (8). Lipid oxidation rates are lower in nutritionally depleted subjects compared with septic patients, regardless of the composition of nutritional intake (9). Adult patients with inactive Crohn's disease have lower fat mass and higher lipid oxidation rates than healthy controls (10). No data concerning glucose, insulin, or substrate metabolism exist in pediatric patients after infliximab therapy. The aim of this study was to describe changes in these parameters after the initial dose of infliximab in pediatric patients with Crohn's disease. Based on the results of prior in vitro and in vivo studies, we hypothesize that the administration of anti-TNF- $\alpha$ therapy to children with active Crohn's disease will result in an increase in lipid oxidation rates, decrease in carbohydrate oxidation rates, and improvement in insulin sensitivity.

Abbreviations: ESR, Erythrocyte sedimentation rate; GIR, Glucose/insulin ratio; HOMA, Homeostasis model assessment; ISI, Insulin sensitivity index; PCDAI, Pediatric Crohn's disease activity index; QUICKI, Quantitative insulin sensitivity check index 


\section{METHODS}

Participants. We recruited children less than 18 years of age with Crohn's disease scheduled to receive their initial infusion of infliximab, an anti-TNF- $\alpha$ antibody. Patients were recruited from the outpatient Pediatric Gastrointestinal Disease Clinic of the James Whitcomb Riley Hospital for Children, Indiana University School of Medicine, Indianapolis, IN. These children were scheduled to receive an i.v. infusion of infliximab due to active Crohn's disease unresponsive to conventional medical therapy, or complicated by fistula formation. The pediatric Crohn's disease activity index (PCDAI) was administered to all patients at each visit. The PCDAI includes subjective reporting of symptoms, physical examination findings, including anthropometric measurements, and three laboratory examinations: hematocrit, erythrocyte sedimentation rate, and serum albumin. The PCDAI has been validated in children and adolescents (11). Informed written consent was obtained from the legal guardian of the child, and each child provided written assent. This study was approved by the Indiana University, Purdue University Indianapolis and Clarian Institutional Review Board, and by the Indiana University School of Medicine General Clinical Research Center Advisory Committee.

Markers of glucose and insulin metabolism. Children with active Crohn's disease underwent outpatient metabolic assessment immediately before and 2 wk after initial infliximab infusion (12). Children were admitted to the General Clinical Research Center for metabolic assessment the morning after an overnight fast. During the fasting portion of the study, a blood sample (3 $\mathrm{mL}$ ) was obtained. Blood was immediately analyzed for plasma glucose concentration, and the remainder of the sample then frozen at $-70^{\circ} \mathrm{C}$ for later analysis. After the fasting portion of the study (approximately $3 \mathrm{~h}$ ), an i.v. solution of glucose $(4.2 \mathrm{mg} / \mathrm{kg} / \mathrm{min})$, lipid $(83 \mathrm{mg} / \mathrm{kg} / \mathrm{h})$ (Intralipid $20 \%$, Baxter Healthcare Corporation, Deerfield, IL), and amino acids $(63 \mathrm{mg} / \mathrm{kg} / \mathrm{h})$ ( $15 \%$ Clinisol, Baxter Healthcare Corporation) was infused for $2.5 \mathrm{~h}$. If this infusion were to continue over $24 \mathrm{~h}$, it would have provided $48 \mathrm{kcal} / \mathrm{kg}, 6 \mathrm{~g} / \mathrm{kg}$ of glucose, $2 \mathrm{~g} / \mathrm{kg}$ of lipid, and $1.5 \mathrm{~g} / \mathrm{kg}$ of protein. A blood sample $(3 \mathrm{~mL})$ was obtained at the end of the parenteral nutrition infusion, analyzed for plasma glucose, and frozen for later analysis.

Blood samples from the fasting and parenterally fed portions of the study were analyzed for plasma insulin concentration [Interassay CV 6.4\%, intraassay CV 4.8\%] (Linco Human Insulin RIA, St. Charles, MO). The glucose/ insulin ratio (GIR), homeostasis model assessment (HOMA), and quantitative insulin sensitivity check index (QUICKI) were calculated for each patient at both fasting and parenterally fed timepoints (13). In addition, the Insulin Sensitivity Index (ISI) (14), which combines fasting and enterally fed data, was adapted for our patients by using the parenteral nutrition infusion time period as the fed state.

Indirect calorimetry. Open circuit indirect respiratory calorimetry (CCM/D Gas Exchange System; Medical Graphics Corporation, St. Paul, $\mathrm{MN}$ ) was performed to measure resting oxygen consumption, carbon dioxide production, and resting energy expenditure as previously described (15). Measurements were taken over $30 \mathrm{~min}$ of the fasting and parenteral nutrition infusion portions of the study while the patients were resting. Urinary nitrogen was not measured. Protein oxidation was derived from phenylalanine conversion to tyrosine by hydroxylation (12), and this value was subtracted from the total resting energy expenditure. The remaining resting energy expenditure was divided between carbohydrate and lipid oxidation based on the RQ (16).

Statistical analysis. All results are reported as the mean \pm SEM. Comparisons within the sample group between pre- and postinfliximab measurements, and between fasting and parenterally fed measurements, were made using the paired $t$ test. Patient data were obtained as part of a protein metabolism study, on which sample size was based (12). Available data from the full sample size was used for this study. A $p<0.05$ was considered statistically significant.

\section{RESULTS}

Patient characteristics. Eleven patients completed the study; six were male and five were female. Nine patients were white and two were African-American. The mean age of the patients was $15.1 \pm 0.3 \mathrm{yr}$. At the time of enrollment, the mean weight Z-score was $-0.76 \pm 0.29$, the mean height Z-score was $-0.69 \pm 0.48$, and the mean BMI Z-score was $-0.30 \pm 0.46$. The mean PCDAI of the patients decreased significantly $(p<0.01)$ from $23 \pm 3$ to $12 \pm 3$ after infliximab. The mean erythrocyte sedimentation rate decreased significantly $(p<0.01$ ) from $24 \pm 3$ to $12 \pm 2 \mathrm{~mm} / \mathrm{h}$ after infliximab. Three of the patients were receiving a weaning dose of oral corticosteroids at the time of the study, and the mean doses of corticosteroids before and $2 \mathrm{wk}$ after the dose of infliximab were $25 \pm 5$ and $10 \pm 6 \mathrm{mg} / \mathrm{d}$, respectively.

Glucose and insulin metabolism. No significant differences in plasma glucose and insulin levels between pre- and postinfliximab measurements were detected in either the fasting or parenterally fed states (Table 1). When the three patients on concomitant corticosteroids were excluded, no additional significant changes were noted. No significant differences in GIR, HOMA, or QUICKI were detected between pre- and postinfliximab measurements in either the fasting or parenterally fed states (Table 1). No significant difference in the adapted ISI was detected between pre- and postinfliximab measurements (Table 1). When the three patients on concomitant corticosteroids were excluded, no significant changes were noted.

Indirect calorimetry. Indirect calorimetry data were available for seven patients in the fasting and parenterally fed states. In the fasting state, no significant change in resting energy expenditure (preinfliximab: $30.0 \pm 1.1 \mathrm{kcal} / \mathrm{kg} / \mathrm{d}$; postinfliximab $29.0 \pm 1.4 \mathrm{kcal} / \mathrm{kg} / \mathrm{d}$ ) was detected (Fig. 1). No significant change in protein oxidation (preinfliximab: $3.6 \pm$ $0.3 \mathrm{kcal} / \mathrm{kg} / \mathrm{d}$; postinfliximab $3.4 \pm 0.3 \mathrm{kcal} / \mathrm{kg} / \mathrm{d}$ ) was found. Similarly, no significant changes in carbohydrate (preinfliximab: $14.3 \pm 2.0 \mathrm{kcal} / \mathrm{kg} / \mathrm{d}$; postinfliximab $11.9 \pm 2.2 \mathrm{kcal} /$ $\mathrm{kg} / \mathrm{d}$ ) and lipid metabolism (preinfliximab: $12.1 \pm 1.7 \mathrm{kcal} /$ $\mathrm{kg} / \mathrm{d}$; postinfliximab $13.7 \pm 2.8 \mathrm{kcal} / \mathrm{kg} / \mathrm{d}$ ) were detected (Fig. 1). No significant difference in RQ was noted between preand postinfliximab measurements $(0.85 \pm 0.02$ and $0.84 \pm$ 0.02 , respectively). In the parenterally fed state, no significant change in resting energy expenditure (preinfliximab: $32.0 \pm$ $1.3 \mathrm{kcal} / \mathrm{kg} / \mathrm{d}$; postinfliximab $31.2 \pm 1.5 \mathrm{kcal} / \mathrm{kg} / \mathrm{d})$ was detected (Fig. 2). No significant change in protein oxidation

Table 1. Markers of insulin sensitivity*

\begin{tabular}{|c|c|c|c|c|}
\hline \multirow[b]{2}{*}{ Marker } & \multicolumn{2}{|c|}{ Fasting } & \multicolumn{2}{|c|}{ Parenterally fed } \\
\hline & Preinfliximab & Postinfliximab & Preinfliximab & Postinfliximab \\
\hline Glucose (mg/dL) & $88 \pm 2 \dagger$ & $89 \pm 3$ & $119 \pm 5$ & $116 \pm 5$ \\
\hline Insulin $(\mathrm{mU} / \mathrm{mL})$ & $8.6 \pm 1.6$ & $7.0 \pm 1.2$ & $24.8 \pm 6.2$ & $26.7 \pm 6.6$ \\
\hline Gluc/ins ratio & $15.7 \pm 3.3$ & $16.1 \pm 2.2$ & $7.2 \pm 1.2$ & $7.5 \pm 1.5$ \\
\hline HOMA & $34 \pm 6$ & $28 \pm 5$ & $134 \pm 34$ & $139 \pm 34$ \\
\hline \multirow[t]{2}{*}{ QUICKI } & $0.36 \pm 0.01$ & $0.37 \pm 0.01$ & $0.30 \pm 0.01$ & $0.30 \pm 0.01$ \\
\hline & \multicolumn{2}{|c|}{ Preinfliximab } & \multicolumn{2}{|c|}{ Postinfliximab } \\
\hline
\end{tabular}

ISI

$10.3 \pm 2.3$

$10.8 \pm 1.9$

* There were no statistically significant differences between preinfliximab and postinfliximab values in any of the variables.

$\dagger$ Mean \pm SE (all such values). 




Figure 1. Mean ( \pm SE) resting energy expenditure $(\square)$, carbohydrate $(\square)$, lipid $(\square)$ and protein $(Z)$, oxidation in the fasting state before and after the initial dose of infliximab in children with active Crohn's disease. No significant difference was noted between preinfliximab and postinfliximab measurements.

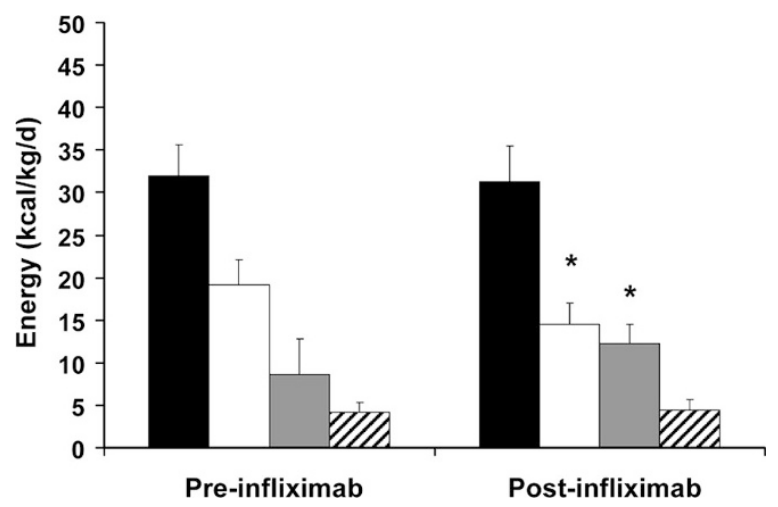

Figure 2. Mean $( \pm$ SE) resting energy expenditure $(\square)$, carbohydrate $(\square)$, lipid $(\square)$ and protein $(\boldsymbol{Z})$, oxidation in the parenterally fed state before and after the initial dose of infliximab in children with active Crohn's disease. A significant difference $(* p<0.05)$ was noted in both carbohydrate and lipid oxidation between preinfliximab and postinfliximab measurements.

(preinfliximab: $4.2 \pm 0.4 \mathrm{kcal} / \mathrm{kg} / \mathrm{d}$; postinfliximab $4.5 \pm 0.5$ $\mathrm{kcal} / \mathrm{kg} / \mathrm{d}$ ) was found. However, energy expenditure from both carbohydrate and lipid metabolism were significantly changed $(p<0.05)$ after infliximab therapy (Fig. 2). Carbohydrate oxidation decreased $24 \%$ from $19.2 \pm 1.1$ to $14.5 \pm 0.9$ $\mathrm{kcal} / \mathrm{kg} / \mathrm{d}$, and lipid oxidation increased $42 \%$ from $8.6 \pm 1.6$ to $12.2 \pm 0.9 \mathrm{kcal} / \mathrm{kg} / \mathrm{d}$ after infliximab therapy. In addition, the RQ decreased significantly $(p<0.05)$ (preinfliximab: $0.91 \pm 0.02$; post infliximab: $0.86 \pm 0.01$ ). When two of the seven patients were excluded due to concomitant corticosteroid use, a significant decrease in RQ and nearly significant decrease in energy expenditure from carbohydrate metabolism remained.

\section{DISCUSSION}

In children with active Crohn's disease receiving their initial dose of infliximab therapy, no significant changes in plasma insulin and glucose, or surrogate measures of insulin resistance (HOMA, ISI, GIR, QUICKI) were observed. The effects of anti-TNF- $\alpha$ therapy on insulin resistance in patients with inflammatory diseases are variable, although our findings confirm prior observations in adult patients with Crohn's disease, in whom no changes in insulin resistance were observed (7). Marked changes in insulin are more frequently observed in traumatized/infected patients than in nutritionally depleted patients (17). However, we observed a significant change in carbohydrate and lipid oxidation rates after infliximab therapy during the provision of parenteral nutrition. This is the first study to demonstrate changes in substrate metabolism because of infliximab therapy. As our prior studies have demonstrated (12), we believe it is important to study these children in both the fasting (catabolic) and fed (anabolic) states to more fully describe the effects of therapy on metabolic outcomes. Our study used parenteral nutrition to more fully control the provision of nutrition. Systemic inflammation may result in increased extraction of amino acids by splanchnic tissue (18). Further studies examining splanchnic protein kinetics in patients with inflammatory bowel disease are warranted.

By utilizing the RQ and the resting energy expenditure, we were able to determine the amount of calories used from both carbohydrate and lipid oxidation in determining resting energy expenditure. After infliximab therapy, we found a significant reduction in RQ and resting energy expenditure from carbohydrate oxidation accompanied by a rise in lipid oxidation during parenteral nutrition infusion. Carbohydrate and lipid oxidation rates demonstrate an inverse correlation, consistent with a glucose-fatty acid cycle (19). In our study, however, we provided equivalent parenteral nutrition at both pre- and postinfliximab timepoints, suggesting that changes in carbohydrate oxidation rates are not the result of the provision of i.v. lipid (which is known to reduce the carbohydrate oxidation rate), but rather the effect of anti-TNF- $\alpha$ therapy. Lipid oxidation decreases significantly during recovery from malnutrition, particularly during parenteral nutrition infusion (20).

Multiple studies in septic or infected patients confirm that acute inflammation results in an increased dependence of lipid oxidation for energy generation $(8,9)$. When these patients are provided carbohydrate in excess of caloric requirements, continued lipid oxidation occurs $(8,17)$. Lipid oxidation rates are lower in nutritionally depleted patients compared with acutely inflamed patients (17), and in vitro data suggests that TNF- $\alpha$ may inhibit lipid oxidation. In rat hepatocytes, TNF- $\alpha$ administration resulted in decreased fatty acid oxidation, which was enhanced by either IL-1 or IL-6 (21). Similarly, when differentiated human preadipocytes were treated with TNF- $\alpha$ for $48 \mathrm{~h}$, expression of electron transport genes was downregulated, and fatty acid oxidation was decreased by $30 \%$ (22). Finally, in TNF- $\alpha$ transgenic mice, hepatic mRNA and activities of carnitine palmitoyltrasferase-II and mitochondrial HMG-CoA synthase, fatty acid oxidation, fatty acyl-CoA oxidase, and fatty acid synthase were reduced (23).

Interpreting findings in pediatric patients with Crohn's disease requires care, as these patients suffer from both chronic inflammation, partly TNF- $\alpha$ mediated, and frequently from malnutrition, mediated by anorexia, malabsorption, and inflammation. Extrapolating data from acutely inflamed patients (i.e., trauma, sepsis) to pediatric inflammatory bowel disease (a chronic inflammatory state) seems fraught with potential error. Rather, the effects of chronic inflammation and malnutrition may both affect substrate metabolism, and only by correcting both can these children reach optimal growth. Given prior in vitro data, the administration of anti-TNF- $\alpha$ 
antibody would seem likely to increase lipid oxidation, as we have observed in this study.

Changes in body composition after corticosteroid therapy may include acquisition of fat mass and obesity. In children with steroid-sensitive nephrotic syndrome, who do not have systemic inflammation, long-term corticosteroid use resulted in obesity, high adiposity, and relatively low appendicular lean mass (24). In children with rheumatic disease, corticosteroid use greater than 1 year resulted in decreased lean mass and significantly higher fat mass (25). In children with active inflammatory bowel disease, concomitant treatment with short-term parenteral nutrition and corticosteroids resulted in predominant fat deposition in the extremities (26). The effects of infliximab seem to contrast those of corticosteroids, which seem to promote fat deposition, perhaps in part due to reduced fat oxidation. Although three of the patients were on weaning doses of corticosteroids during the study, we believe the metabolic changes observed, especially over the 2 wk timeframe, were more likely a result of anti-TNF- $\alpha$ therapy. This was confirmed by obtaining nearly identical results when the patients receiving corticosteroids were excluded. Given that lean body mass acquisition is critical for growth and bone mineral content acquisition, infliximab may prove superior to corticosteroids in optimizing these outcomes. Long-term, larger studies of children receiving anti-TNF- $\alpha$ therapy are needed to determine whether changes in body composition and bone mineral density result from the metabolic changes we have observed.

We have previously reported decreased protein turnover in children with active Crohn's disease after infliximab therapy (12), and no difference in protein oxidation was noted after infliximab therapy in either the fasting or parenterally fed state. We believe the results of this study add to our understanding of the metabolic alterations in active Crohn's disease, as well as the effects of anti-TNF- $\alpha$ therapy. Protein, carbohydrate, and lipid metabolism are obviously linked, and there is evidence that conversion of amino acid to carbohydrate continues during active inflammation, even in the setting of exogenous glucose infusion (27). In these children, there appears to be increased oxidation of carbohydrate in the inflamed state, which is reduced by antiTNF- $\alpha$ therapy. Further studies of long-term maintenance infliximab therapy, and analysis of body composition, carbohydrate and fat metabolism, and the effects of enteral nutrition, will provide additional information about substrate metabolism in these children.

\section{REFERENCES}

1. Di Rocco P, Manco M, Rosa G, Greco AV, Mingrone G 2004 Lowered tumor necrosis factor receptors, but not increased insulin sensitivity, with infliximab. Obes Res 12:734-739

2. Yazdani-Biuki B, Stelzl H, Brezinschek HP, Hermann J, Mueller T, Krippl P, Graninger W, Wascher TC 2004 Improvement of insulin sensitivity in insulin resistant subjects during prolonged treatment with the anti-TNF-alpha antibody infliximab. Eur J Clin Invest 34:641-642
3. Gonzalez-Gay MA, De Matias JM, Gonzalez-Juanatey C, Garcia-Porrua C, SanchezAndrade A, Martin J, Llorca J 2006 Anti-tumor necrosis factor-alpha blockade improves insulin resistance in patients with rheumatoid arthritis. Clin Exp Rheumatol 24:83-86

4. Tam LS, Tomlinson B, Chu TT, Li TK, Li EK 2007 Impact of TNF inhibition on insulin resistance and lipids levels in patients with rheumatoid arthritis. [see comment]. Clin Rheumatol 26:1495-1498

5. Kiortsis DN, Mavridis AK, Vasakos S, Nikas SN, Drosos AA 2005 Effects of infliximab treatment on insulin resistance in patients with rheumatoid arthritis and ankylosing spondylitis. Ann Rheum Dis 64:765-766

6. Huvers FC, Popa C, Netea MG, van den Hoogen FH, Tack CJ 2007 Improved insulin sensitivity by anti-TNFalpha antibody treatment in patients with rheumatic diseases. Ann Rheum Dis 66:558-559

7. Gentile S, Guarino G, Bizzarro A, De Bellis A, Torella R 2002 Infliximab does not interfere with insulin secretion, insulin resistance and production of GAD and islet cell antibodies in patients with Crohn's disease. Diabetes Obes Metab 4:276-277

8. Askanazi J, Carpentier YA, Elwyn DH, Nordenstrom J, Jeevanandam M, Rosenbaum SH, Gump FE, Kinney JM 1980 Influence of total parenteral nutrition on fuel utilization in injury and sepsis. Ann Surg 191:40-46

9. Nanni G, Siegel JH, Coleman B, Fader P, Castiglione R 1984 Increased lipid fuel dependence in the critically ill septic patient. J Trauma 24:14-30

10. Capristo E, Mingrone G, Addolorato G, Greco AV, Gasbarrini G 1998 Metabolic features of inflammatory bowel disease in a remission phase of the disease activity. J Intern Med 243:339-347

11. Hyams JS, Ferry GD, Mandel FS, Gryboski JD, Kibort PM, Kirschner BS, Griffiths AM, Katz AJ, Grand RJ, Boyle JT, Michener WM, Levy JS, Lesser ML 1991 Development and validation of a pediatric Crohn's disease activity index. J Pediatr Gastroenterol Nutr 12:439-447

12. Steiner SJ, Pfefferkorn MD, Fitzgerald JF, Denne SC 2007 Protein and energy metabolism response to the initial dose of infliximab in children with Crohn's disease. Inflamm Bowel Dis 13:737-744

13. Keskin M, Kurtoglu S, Kendirci M, Atabek ME, Yazici C 2005 Homeostasis model assessment is more reliable than the fasting glucose/insulin ratio and quantitative insulin sensitivity check index for assessing insulin resistance among obese children and adolescents. [see comment]. Pediatrics 115:e500-e503

14. Matsuda M, DeFronzo RA 1999 Insulin sensitivity indices obtained from oral glucose tolerance testing: comparison with the euglycemic insulin clamp. [see comment]. Diabetes Care 22:1462-1470

15. Denne SC, Kalhan SC 1986 Glucose carbon recycling and oxidation in human newborns. Am J Physiol 251:E71-E77

16. Elia M, Livesey G 1992 Energy expenditure and fuel selection in biological systems: the theory and practice of calculations based on indirect calorimetry and tracer methods. World Rev Nutr Diet 70:68-131

17. Nordenstrom J, Carpentier YA, Askanazi J, Robin AP, Elwyn DH, Hensle TW, Kinney JM 1982 Metabolic utilization of intravenous fat emulsion during total parenteral nutrition. Ann Surg 196:221-231

18. Fong Y, Matthews DE, He W, Marano MA, Moldawer LL, Lowry SF 1994 Whole body and splanchnic leucine, phenylalanine, and glucose kinetics during endotoxemia in humans. Am J Physiol 266:R419-R425

19. Randle PJ 1998 Regulatory interactions between lipids and carbohydrates: the glucose fatty acid cycle after 35 years. Diabetes Metab Rev 14:263-283

20. Carbonnel F, Messing B, Rimbert A, Rongier M, Koziet J, Darmaun D 1997 Energy and protein metabolism during recovery from malnutrition due to nonneoplastic gastrointestinal disease. Am J Clin Nutr 65:1517-1523

21. Nachiappan V, Curtiss D, Corkey BE, Kilpatrick L 1994 Cytokines inhibit fatty acid oxidation in isolated rat hepatocytes: synergy among TNF, IL-6, and IL-1. Shock $1: 123-129$

22. Dahlman I, Forsgren M, Sjogren A, Nordstrom EA, Kaaman M, Naslund E, Attersand A, Arner P 2006 Downregulation of electron transport chain genes in visceral adipose tissue in type 2 diabetes independent of obesity and possibly involving tumor necrosis factor-alpha. Diabetes 55:1792-1799

23. Glosli H, Gudbrandsen OA, Mullen AJ, Halvorsen B, Rost TH, Wergedahl H, Prydz H, Aukrust P, Berge RK 2005 Down-regulated expression of PPARalpha target genes, reduced fatty acid oxidation and altered fatty acid composition in the liver of mice transgenic for hTNFalpha. Biochim Biophys Acta 1734:235-246

24. Foster BJ, Shults J, Zemel BS, Leonard MB 2004 Interactions between growth and body composition in children treated with high-dose chronic glucocorticoids. Am J Clin Nutr 80:1334-1341

25. Mul D, van Suijlekom-Smit LW, ten Cate R, Bekkering WP, de Muinck KeizerSchrama SM 2002 Bone mineral density and body composition and influencing factors in children with rheumatic diseases treated with corticosteroids. J Pediatr Endocrinol Metab 15:187-192

26. Lin CH, Lerner A, Rossi TM, Feld LG, Riddlesberger MM, Lebenthal E 1989 Effects of parenteral nutrition on whole body and extremity composition in children and adolescents with active inflammatory bowel disease. JPEN J Parenter Enteral Nutr 13:366-371

27. Long CL 1977 Energy balance and carbohydrate metabolism in infection and sepsis. Am J Clin Nutr 30:1301-1310 